\title{
Analisis Penerapan E-Filling Dimasa Pandemi Covid 19 Sebagai Upaya Meningkatkan Kepatuhan Wajib Pajak Orang Pribadi
}

\author{
Rusli Amrul \\ Sekolah Tinggi Ilmu Ekonomi AMM Mataram \\ Email : rusliamr@gmail.com
}

\begin{abstract}
The purpose of this research is to determine the application of e-filling during the pandemic in increasing individual taxpayer compliance in submitting annual tax. The data analysis technique used in this study is a qualitative descriptive analysis method, namely by collecting data, processing data, analyzing data, conclude and providing interpretation. The results of the study are Tax Service Office in West Mataram in implementing e-filling during the covid 19 pandemic has been in accordance with the procedures based on tax laws and regulations on tax administration. The implementation of social distancing during the COVID-19 pandemic is one of the obstacles in disseminating the form of tax annual reports to taxpayers through e-filling. The compliance of individual taxpayers during the COVID-19 pandemic in reporting annual tax through e-filing is more constrained because individual taxpayers mostly report annual tax at the end of the reporting deadline, not all taxpayers understand technology such as computers, internet access and email, lack of knowledge of individual taxpayers in filling out annual tax report online so that there are many errors in filling out annual tax report. The network system on the website of the Directorate General of Taxes is often disrupted due to too many individual taxpayers accessing the website in the month of the annual tax report.
\end{abstract}

Keywords : e-filling, Annual Tax Report, Taxpayer compliance, Pandemic Period

\section{PENDAHULUAN}

Penyebaran virus corona menyebar hampir ke setiap negara termasuk negara Indonesia, bahkan Presiden RI Joko Widodo secara resmi menetapkan COVID-19 sebagai bencana nasional. Penetapan itu dinyatakan melalui Keputusan Presiden (Keppres) Republik Indonesia Nomor 12 Tahun 2020 tentang Penetapan Bencana Non-Alam Penyebaran Corona Virus Disease 2019 (Covid-19) sebagai Bencana Nasional (bnpb.go.id). Bencana Virus ini mempengaruhi berbagai aspek, salah satunya menghambat laju perekonomian nasional. Berbagai aktivitas perekonomian masyarakat terhambat terutama akibat protocol kesehatan berupa social distancing yang harus diterapkan sampai saat ini. Berbagai macam upaya yang dilakukan oleh pemerintah guna untuk menekan angka penyebaran virus corona. Bekerja dari rumah atau work from home yang dilaksanakan saat ini merupakan tindak lanjut atas imbauan Presiden Joko Widodo pada konferensi pers di Istana Bogor Jawa Barat. Presiden mengimbau agar dapat meminimalisasi penyebaran virus corona, masyarakat diminta untuk bekerja, belajar, dan beribadah dari rumah, salah satunya menciptakan sistem bekerja dari rumah.(djkn.kemenkeu.go.id). Masyarakat disarankan untuk melakukan social distancing untuk mengurangi peluang penularan virus ini. Salah satu yang diterapkan oleh sebagian besar kantor guna untuk mengurangi peluang virus ini ialah dengan menerapkan metode kerja Work FromHome (WFH).

Banyak kendala yang dihadapi semenjak diterapkannya WFH ini, karena semua pekerjaan dituntut dilakukan dari rumah. Pemerintah berupaya agar tidak semakin 
meluasnya penyebaran virus ini. Menyikapi situasi dan informasi yang terus berkembang terkait penyebaran Covid-19, Kementerian Keuangan telah mengambil berbagai kebijakan terkait, diantaranya adalah dengan mengeluarkan surat edaran yang berisi kebijakan bekerja dari rumah atau work from home bagi para pegawai Kementerian Keuangan (djkn.kemenkeu.go.id). Kantor Pelayanan Pajak (KPP) salah satu lembaga Kementrian Keuangan dan merupakan lembaga pelayanan bagi Wajib Pajak yang setiap hari melaksanakan kewajiban melayani laporan Wajib Pajak. Setiap perusahaan berkewajiban untuk melaporkan pajak penghasilan maupun pajak pertambahan nilai yang dilaporkan rutin setiap bulannya. Pelaporan pajak dapat dilakukan secara manual ke kantor pajak maupun dilakukan secara elektronik. Namun ditengah pandemi corona saat ini, pelayanan tatap muka di kantor pajak dihentikan dan secara otomatis untuk pelaporan secara manual tidak dapat dilakukan.

Berdasarka Peraturan Direktur Jenderal Pajak nomor per 06/pj/2020 Tentang Tata cara penyampaian, penerimaan, dan pengolahan surat pemberitahuan pajak penghasilan tahun pajak 2019 sehubungan dengan pandemi corona virus disease 2019 maka pelaporan pajak harus melalui e-Filing; pos dengan bukti pengiriman surat; atau perusahaan jasa ekspedisi atau jasa kurir dengan bukti pengiriman surat. Sementara batas waktu pelaporan pajak tetap diberlakukan sebagaimana mestinya sesuai dengan Undang-Undang. Wajib pajak harus mentaati peraturan sesuai dengan peraturan perundang-undangan tersebut, karena jika pelaporannya melebihi batas waktu yang telah ditentukan, maka akan dikenakan denda oleh Direktorat Jenderal Pajak. Jadi harus ada solusi yang tepat dilakukan saat situasi seperti ini agar menghindari terjadinya telat pelaporan pajak.

Solusi yang tepat yang harus dilakukan saat situasi seperti ini agar mempermudah pelaporan pajak dengan melaporkan pajak secara online menggunakan aplikasi e-Filing. Penggunaan aplikasi e-Filng sudah ditetapkan dari tahun 2004. Melalui keputusan Direktorat Jendral Pajak Nomor Kep-88/PJ/2004 pada bulan Mei tahun 2004 secara resmi diluncurkan produk e-filling atau electronic Filing System. Dalam Keputusan Dirjen Pajak Nomor KEP88/PJ/2004 tentang Penyampaian SPT secara elektronik dilakukan melalui Perusahaan Penyedia Jasa (Application Service Provider) yang ditunjuk oleh Direktorat Jendral Pajak untuk pengaturannya lebih lanjut maka dikeluarkanlah Peraturan Direktorat Jendral Pajak Nomor KEP05/PJ/2005 tentang Tata Cara Penyampaian Surat Pemberitahuan secara Elektronik (e-filing) melalui Perusahaan Penyedia Jasa (ASP). Aplikasi E-SPT atau disebut elektrnonik E-SPT adalah Surat Pemberitahuan Masa atau Surat Pemberitahuan Tahunan yang berbentuk formulir elektronik dalam media computer. E-filling adalah suatu cara penyampaian SPT Elektronik yang dilakukan secara online pada website Direktorat Jendral Pajak (http://djponline.pajak.go.id) atau penyedia jasa aplikasi atau Application Service Provider (ASP).

E-filling merupakan layanan pengisian dan penyampaian Surat Pemberitahuan Wajib Pajak yang dilakukan secara elektronik melalui sistem online yang real time kepada Direktorat Jendral Pajak melalui internet pada wibesite Direktorat Jendral Pajak.(www.kemenkeu.go.id). Dengan diterpakannya sistem e-filling, bertujuan untuk memudahkan wajib pajak dalam melaporkan kewajiban perpajakannya sehingga dapat membantu pemerintah dalam hal pengadministrasian agar penerimaan pajak terus meningkatkan dan mendorong wajib pajak untuk lebih jujur, patuh, konsisten dan sukarela dalam melaksanakan kewajiban pajaknya.

Kantor Pelayanan Pajak (KPP) Mataram Barat salah satu kantor pelayanan pajak di Mataram berbagai cara dilakukan untuk mensosialisasikan penggunaan E-filling dalam melakukan pelaporan dalam masa pandemic, meskipun berbagai kendala yang dihadapi oleh wajip pajak khususnya terkait dengan sinyal internet, namun penggunaan E-filling ini terus disosialissasikan agar Wajip Pajak tidak terlambat dalam melaporkan kewajiban pajaknya dan terhindar dari denda pajak. Dengan adanya E-filling ini diharapkan agar dapat mempermudah Wajib Pajak dalam melaksanakan kewajibannya terutama dalam pelaporan SPT tanpa harus mengantri di Kantor Pelayanan Pajak sehingga dirasa lebih efektif dan efisien di masa pandemic covid-19. Wajib pajak dapat melaporkan SPT dimana saja dan kapan saja selama 24 jam dalam 7 
hari, dimana akan dikirim langsung ke database Direktorat Jendral Pajak dengan fasilitas internet yang disalurkan melalui website DJP

Berdasarkan penjelasan diatas penerapan e-filing dimasa pandemi sebagai sarana pelaporan SPT tahunan diharapkan akan meningkatkan kepatuhan wajib pajak di KPP Pratama Mataram Barat. Oleh karena itu peneliti tertarik untuk melakukan Analisis Penerapan E-Filling dimasa Pandemi Covid 19 sebagai Upaya Meningkatkan Kepatuhan Wajib Pajak Dalam Penyampaian Surat Pemberitahuan (SPT) Tahunan Pada Kantor Pelayanan Pajak (KPP) Pratama Mataram Barat.

\section{TINJAUAN PUSTAKA}

\section{Kepatuhan Wajib Pajak}

Menurut Supramono dan Damayanti (2005) kepatuhan wajib pajak berarti keadaan wajib pajak melaksanakan hak dan kewajibannya secara disiplin, sesuai dengan peraturan undangundang serta tata cara perpajakan yang berlaku. Kepatuhan wajib pajak diartikan sebagai kesadaran wajib pajak untuk memenuhi kewajibannya untuk mengisi formulir pajak, dan menghitung sendiri jumlah pajak yang terutang dengan benar. Kepatuhan biasannya berkisar pada istilah tingkat dimana wajib pajak mematuhi undang-undang dan administrasi perpajakan, tanpa perlu kegiatan penegak hukum.

Ada dua macam kepatuhan, yaitu kepatuhan Formal dan kepatuhan material. Kepatuhan Formal adalah kepatuhan dimana wajib pajak memenuhi kewajiban perpajakan secara formal sesuai dengan perundang-undangan perpajakan yang berlaku. Misalnya ketentuan tentang batas penyampaian SPT. Sedangkan kepatuhan material adalah suatu keadaan dimana wajib pajak secara subtantif memenuhi semua ketentuan material perpajakan, yakni sesuai dengan isi dan jiwa undang-undang perpajakan, wajib pajak yang memenuhi kewajiban material dalam mengisi SPT PPh Tahunan adalah wajib pajak yang mengisi dengan baik, benar dan jujur sesuai dengan ketentuan perundang-undangan perpajakan.

Pengukuran Kepatuhan Berdasarkan Peraturan Menteri Keuangan Nomor 192/PMK.03/2007, Wajib Pajak termasuk dalam kategori Wajib Pajak patuh apabila memenuhi kriteria sebagai berikut:

a. Tepat waktu dalam menyampaikan surat pemberitahuan.

b. Tidak mempunyai tunggakan pajak untuk semua jenis pajak, kecuali telah memperoleh izin untuk mengangsur atau menunda pembayaran pajak.

c. Tidak pernah dijatuhi hukuman karena melakukan tindak pidana di bidang perpajakan dalam jangka waktu lima tahun terakhir.

d. laporan Wajib Pajak yang keuangannya tiga tahun terakhir diaudit oleh akuntan publik atau lembaga pengawas keuangan pemerintah dengan pendapat wajar tanpa pengecualian.

Menurut Undang - undang Nomor 16 Tahun 2009 tentang perubahan atas Undang undang Nomor 6 Tahun 1983 tentang Ketentuan Umum dan Tata Cara Perpajakan, Wajib Pajak adalah orang pribadi atau badan, meliputi pembayar pajak, pemungut pajak dan pemungut pajak yang mempunyai hak dan kewajiban perpajakan sesuai dengan ketentuan peraturan perundang undangan perpajakan. Dan Wajib Pajak Orang Pribadi adalah setiap orang yang mempunyai penghasilan neto dalam satu tahun pajak diatas Penghasilan Tidak Kena pajak (PTKP).

\section{Jenis Pelaporan SPT Online Pajak Pribadi}

Layanan e-Filing pajak dapat Anda akses dengan mudah melalui website Direktorat Jendral Pajak atau Penyedia Layanan SPT Elektronik atau Application Service Provider (ASP) resmi. Saat ini, Direktorat Jenderal Pajak melayani penyampaian 3 jenis SPT WP Orang Pribadi, yaitu: 


\section{a. Formulir SPT 1770 SS (Sangat Sederhana)}

Kriteria: Wajib Pajak Orang Pribadi dengan penghasilan bruto selain dari usaha dan/atau pekerjaan bebas kurang dari Rp 60 juta per tahun dari satu atau lebih pemberi kerja Penghasilan lain.

b. Formulir SPT 1770 S (Sederhana)

Kriteria: Wajib Pajak Orang Pribadi dengan penghasilan bruto sama dengan atau lebih dari Rp60 juta dari usaha dan/atau pekerjaan bebas dari satu pemberi kerja.

c. Formulir SPT 1770

Formulir 1770 khusus bagi Wajib Pajak Orang Pribadi yang menerima penghasilan dari usaha atau pekerjaan bebas, penghasilan dari satu atau lebih pemberi kerja, penghasilan yang dikenakan PPh final, atau penghasilan dari dalam negeri maupun luar negeri lainnya.

\section{Elektronik SPT (E-SPT) \\ Pengertian E-SPT}

Dalam mewujudkan sistem administrasi perpajakan modern, pemerintah menyediakan aplikasi yang dapat digunakan oleh wajib pajak untuk melakukan pengisian dan pelaporan secara cepat, tepat dan akurat. Berdasarkan Peraturan Direktorat Jendral Pajak Nomor PER-03/PJ/2015 tentang Tata Cara Penyampaian Surat Pemberitahuan secara Elektronik. "E-SPT adalah aplikasi SPT elektronik yang disediakan oleh Direktorat Jendral Pajak. Tata cara dan Prosedur Penyampaiannya E-SPT tersebut dengan secara langsung atau melaui pos/perusahaan jasa ekspedisi/kurir. Melalui laman Direktorat Jendral Pajak. Melalui penyalur SPT Elektronik. Melalui saluran suara digital yang ditetapkan oleh Direktorat Jendral Pajak untuk Wajib Pajak tertentu. Melalui jaringan komunikasi data yang terhubung khusus antara Direktorat Jendral Pajak dengan Wajib Pajak:

Dalam peraturan Direktorat Jendral Pajak (2015) E-SPT merupakan Surat Pemberitahuan beserta lampiran-lampirannya dalam bentuk digital dan dilaporkan secara elektronik atau denganmenggunakan media computer yang digunakan untuk membantu wajib pajak dalam melaporkan perhitungan dan pembayaran pajak yang terutang sesuai dengan ketentuan peraturan perundang-undangan yang berlaku. Menurut Liberti $(2008 ; 35)$ yang dimaksud dengan E-SPT adalah surat pemberitahuan yang di sampaikan dalam bentuk digital ke KPP secara Elektronik atau dengan menggunakan media komputer.

Adapun tata cara pelaporan e-SPT adalah sebagai berikut:

a. Wajib pajak melakukan instalasi aplikasi e-SPT pada sistem komputer yang digunakan untuk keperluan administrasi perpajakannya.

b. Wajib pajak menggunakan aplikasi e-SPT untuk merekam data-data perpajakan yang akan dilaporkan.

c. Wajib pajak yang telah memiliki sistem administrasi keuangan/perpajakan sendiri dapat melakukan proses import data dari sistem yang dimiliki wajib pajak ke dalam aplikasi e-SPT dengan mengacu kepada format data yang sesuai dengan aplikasi e-SPT.

d. Wajib pajak mencetak bukti potong/pungut dengan menggunakan aplikasi e-SPT dan menyampaikannya kepada pihak yang dipotong/dipungut.

e. Wajib pajak menandatangani SPT Masa PPh/PPN dan/atau SPT Tahunan.

f. Wajib pajak membentuk file data SPT dengan menggunakan aplikasi e-SPT dan disimpan dalam media elektronik (CD, flash disk).

g. Wajib pajak menyampaikan e-SPT ke KPP tempat wajib pajak terdaftar.

\section{E-filling}

\section{a. Pengertian e-filling}

Berdasarkan Keputusan Direktorat Jendral Pajak Nomor KE-88/PJ/2004 tanggal 14 Mei 2004 KEP-05/PJ/2005 tanggal 12 Januari 2005 tentang Tata Cara Penyampaian Surat Pemberitahuan Secara Elektronik (e-filling) melalui Perusahaan Penyedia Jasa Aplikasi 
(ASP) ,"e-filling adalah Surat Pemberitahuan Masa atau Tahunan yang berbentuk formulit elektronik dalam media komputer, dimana penyampaiannya dilakukan secara elektronik dalam bentuk data digital yang ditransfer atau disampaikan ke Direktorat Jendral Pajak melalui Perusahaan Penyedia Jasa Aplikasi atau Application Service Provider (ASP) yang telah ditunjuk oleh DJP dengan proses yang terintegrasi dan real time".

\section{b. Syarat E-filling}

Berdasarkan Peratuan Direktorat Jendral Pajak Nomor PER-01/PJ/2014 untuk dapat menggunakan fasilitas e-filling Wajib Pajak harus memenuhi syarat-syarat berikut:

1. Sudah terdaftar sebagai Wajib Pajak (WP) atau sudah memiliki NPWP (Nomor Pokok Wajib Penduduk).

2. Kartu identitas diri.

3. Nomor telepon dan alamat email yang aktif.

4. Dokumen yang digunakan mengisi SPT.

5. Memiliki PC yang memadai dan terkoneksi ke internet.

Adapun syarat-syarat Wajib Pajak dapat menikmati layanan e-filling atau pengiriman data atau penyampaian SPT secara elektronik adalah sebagai berikut,

1. E-fin yang diperoleh dari KPP

2. Memiliki aplikasi SPT dan submission data ke ASP laporpajak.com

3. Sertifikat Digital (Digital Certifict) yang didapatkan setelah melakukan registrasi e-filling.

\section{c. Dasar Hukum}

Wajib Pajak yang menggunakan sistem e-filling ini mendapatkan perlindungan hokum. Direktorat Jendral Pajak dapat memberikan jaminan kepada Wajib Pajak atas keamanan, kerahasian dan keasliannya. Tanda tangan digital yang dibutuhkan dalam SPT elektronik merupakan proses penyisipan status objek hokum pada informasi, bahwa pengiriman informasi adalah subjek hokum yang benar.

1. Keputusan Direktorat Jendral Pajak Nomor PER-39/PJ/2011 Pasal (1) tentang Tata Cara Penyampaian Surat Pemberitahuan Tahunan bagi Wajib Pajak Orang Pribadi secara $e$ filling yang dimaksud dengan :

a) SPT Tahunan adalah SPT Pajak Penghasilan untuk suatu Tahun Pajak atau Bagian Tahun Pajak.

b) E-SPT adalah data SPT Wajib Pajak dalam bentuk elektronik yang dibuat oleh Wajib Pajak dengan menggunkan aplikasi E-SPT yang disediakan oleh DJP.

c) E-filling adalah suatu cara penyampaian SPT Tahuna secara elektronik yang dilakukan secara on-line atau real time melalui internet pada website Direktorat Jendra Pajak (www.pajak.go.id) atau Penyedia Jasa Aplikasi atau Application Service Provides (ASP).

d) Electronic Filling Identification Number (e-FIN) adalah nomor identitas yang diterbitkan oleh Kantor Pelayanan Pajak kepada Wajib Pajak yang mengajukan permohonan untuk melaksanakan e-filling.

e) Bukti Penerimaan Elektronik adalah informasi yang meliputi nama, NPWP, tanggal, jam, Nomor Tanda Terima Elektronik yang terterapada hasil cetakan bukti penerimaan, dalam hal e-filling dilakukan melalui website DJP atau informasi yang meliputi nama, NPWP, tanggal, jam, Nomor Tanda Terima Elektronik dan Nomor Transaksi Pengiriman ASP serta nama Perusahaan Penyedia Jasa (ASP) yang tertera pada hasil cetakan induk, dalam hal e-filling dilakukan melauli Penyedia Jasa Aplikasi. 
2. Peraturan Direktorat Jendral Pajak No. PER-26/PJ/2012 tentang Tata Cara Penerimaan dan Pengolahan Surat Pemberitahuan Tahunan.

3. Peraturan Direktorat Jendral Pajak No. PER-26/PJ/2014 tentang Tata Cara Penyampaian Surat Pemberitahuan Tahunan bagi Wajib Pajak Orang Pribadi yang menggunakan formulir 1770, 1770S atau 1770SS secara e-filling melalui website DJP.

4. Peratura Direktorat Jendral Pajak Nomor: PER-01/PJ/2016 tentang Tata Cara Penerimaan dan Pengolahan SPT.

5. Peraturan Direktorat Jendral Pajak Nomor PER-41/PJ/2015 tentang Pengamanan Transaksi Elektronik Layanan Pajak Online.

\section{d. Prosedur E-filling}

Berdasarkan Peraturan Direktorat Jendral Pajak Nomor PER-01/PJ/2014 wajib pajak orang pribadi mengajukan permohonan untuk memperoleh e-fin terlebih dahulu dengan langkahlangkah sebagai berikut:

1. Wajib Pajak Orang Pribadi mengajukan permohonan e-fin ke Kantor Pelayanan Pajak tempat wajib pajak terdaftar atau secara online melalui website Direktorat Jendral Pajak.

2. Jika pendaftaran dilakukan melalui Kantor Pelayanan Pajak tempat wajib pajak terdaftar maka wajib pajak akan diminta mengisi formulir, NPWP dan KTP dan langsung akan diproses paling lama selama 1 hari kerja.

3. Jika pendaftaran dilakukan secara online melali website Direktorat Jendral Pajak, maka wajib pajak diminta melakukan pengisian formulir secara online yang kemudian e-fin dikirim ke alamat wajib pajak yang dikirimkan melalui pos, perusahaan jasa ekspedisi, atau jasa kurir selama 3 hari kerja sejak proses pengiriman.

4. Setelah wajib pajak mendapatkan nomor e-fin, wajib pajak mendaftarkan diri sebagai wajib pajak e-filling palaing lama 30 (tiga puluh) hari kalender sejak terbitnya e-fin dengan cara :

a. Buka menu e-fillin di situs DJP www.pajak.go.id

b. Masukan NPWP dan E-FIN.

c. Isikan data email, nomor handphone, dan password.

d. Lakukan konfirmasi balasan pada email dan handphone.

e. Jika dalam waktu 30 (tiga puluh) hari wajib pajak tidak mendaftarkan diri sebagai wajib pajak e-filing maka wajib pajak dapat mengajukan kembali permohonan e-fin secara online melalui website Direktorat Jendral Pajak atau langsung Kantor Pelayanan Pajak.

5. Menyampaikan SPT Tahunan secara e-filling melalui www.pajak.go.id :

a. Login aplikasi e-filling menggunakan email sebagai username dan password,

b. Mengisi E-SPT dengan benar, lengkap dan jelas,

c. Meminta kode verivikasi untuk penyampaian SPT,

d. Menandatangani E-SPT dengan mengisi kode verifikasi,

e. Mengirim E-SPT secara e-filling,

f. Menerima verivikasi melalui email dan SMS,

g. Menerima bukti penerimaan elektronik.

\section{METODE PENELITIAN}

\section{Jenis Penelitian}

Jenis penelitian yang digunakan penulis penelitian deskriptif kualitatif, yang memiliki tujuan untuk mendiskripsikan fenomena yang ada secara kualitatif dengan harapan dapat membuka potensi interprestasi-interprestasi subjektif, penelitian ini termaksud penelitian 
deskriptif kualitatif dimana data yang diperoleh digunakan untuk menganalisis penerapan e-filing sebagai upaya meningkatkan kepatuhan wajib pajak dalam menyampaikan SPT pada KPP Pratama Mataram Barat.

\section{Metode pengumpulan Data}

Dalam pengumpulan data metode yang digunakan penulis adalah sebagai berikut:

a. Metode Wawancara

Wawancara merupakan teknik pengumpulan data yang digunakan untuk lebih mendalami responden secara spesifik yang dapat dilakukan dengan tatap muka ataupun komunikasi menggunakan alat bantu komunikasi. Wawancara dilaksanakan langsung dengan kepala bagian divisi pelayanan, ekstensivikasi, kepala bagian umum dan pengolahan data dan informasi. KPP Pratama Mataram Barat.

b. Dokumentasi

Data yang yang digunakan adalah data statistik tingkat kepatuhan wajib pajak orang pribadi dalam menggunakan e-filing sebagai sarana pelaporan SPT tahunan orang pribadi

\section{Jenis dan Sumber Data \\ Jenis Data}

Jenis data yang digunakan dalam penelitian ini adalah data kuantitatif yakni berupa data yang meliputi jumlah wajib pajak orang pribadi terdaftar dan jumlah penerimaan SPT tahunan dari tahun 2017 sampai dengan tahun 2020.

\section{Sumber Data}

Sumber data yang di gunakan dalam penelitian yaitu:

a. Data Primer

Data primer yaitu data yang bersumber dari hasil wawancara (interview) dengan karyawan maupun dengan kepala bagian divisi pelayanan, ekstensivikasi, kepala bagian umum dan pengolahan data dan informasi.

b. Data Sekunder

Data sekunder yaitu data yang diperoleh berupa laporan-laporan dan informasi lain dalam bentuk dokumentasi yang bersumber dari KPP Pratama Mataram Barat. Data sekunder yang dimaksud yaitu seperti data statistik yang diperoleh meliputi jumlah wajib pajak orang pribadi terdaftar dan total penerimaan SPT tahunan sebagai perbandingan antara SPT manual dengan e-filing serta kelebihan dan kelemahan yang dihadapi dalam penerapan e-filing sebagai upaya meningkatkan kepatuhan wajib pajak dalam penyampaian SPT tahunan pada KPP Pratama Mataram Barat

\section{Teknik Analisis Data}

Teknik analisis data yang digunakan dalam penelitian ini adalah metode analisis deskriptif kualitatif yaitu penulis melakukan pengumpulan data, mengolah data, menganalisis data, mengambil kesimpulan dan memberikan intepretasi.

\section{HASIL DAN PEMBAHASAN}

Penelitian ini untuk menganalisa penerapan e-filling yang telah diterapkan oleh KPP Pratama Mataram Barat dalam rangka meningkatakan pelayanan kepada wajib pajak orang pribadi di masa pandemi. Dari penelitian ini penulis akan menuliskan hasil penelitian tentang apa saja yang telah dilakukan oleh KPP Pratama Mataram Barat dalam memaksimalkan pelayanan kepada wajib pajak orang pribadi. Pada penelitian ini juga akan disajikan hasil penelitian yang didapat dari wawancara langsung dengan informan yang telah dipilih. Informan tersebut adalah pegawai pada Seksi Pelayanan di KPP Pratama Mataram Barat yang terkait langsung dengan 
pelayanan pelaporan SPT Tahunan melalui e-filling. Seperti yang telah dijelaskan dalam literarur bahwa penyampaian SPT WP Orang Pribadi ( WPOP )dibagi menjadi 3 yakni SPT 1770 SS (Sangat Sederhana) atau Wajib Pajak Orang Pribadi dengan penghasilan bruto selain dari usaha dan/atau pekerjaan bebas kurang dari Rp 60 juta per tahun dari satu atau lebih pemberi kerja Penghasilan lain, kemudian SPT 1770 S (Sederhana) atau Wajib Pajak Orang Pribadi dengan penghasilan bruto sama dengan atau lebih dari Rp60 juta dari usaha dan/atau pekerjaan bebas dari satu pemberi kerja dan terakhir SPT 1770 atau Wajib Pajak Orang Pribadi yang menerima penghasilan dari usaha atau pekerjaan bebas, penghasilan dari satu atau lebih pemberi kerja, penghasilan yang dikenakan $\mathrm{PPh}$ final, atau penghasilan dari dalam negeri maupun luar negeri lainnya.

Dari data yang diperoleh, jumlah wajib pajak orang pribadi yang melakukan pelaporan SPT tahunan di KPP Pratama Mataram Barat dari tahun 2017-2020 pada table berikut:

Tabel 1. Jumlah Penyampaian SPT Tahunan Menggunakan Formulir 1770 S dan 1770 SS Melalui E-Filling

\begin{tabular}{|c|c|c|}
\hline \multicolumn{3}{|c|}{$\begin{array}{c}\text { JUMLAH PENYAMPAIAN SPT TAHUNAN PAJAK WP OP } \\
\text { MELALUI E-FILLING TAHUN PAJAK 2017-2020 }\end{array}$} \\
\hline TAHUN PAJAK & TAHUN PENERIMAAN & TOTAL \\
\hline 2017 & 2018 & 40,125 \\
\hline 2018 & 2019 & 41,740 \\
\hline 2019 & 2020 & 37,996 \\
\hline 2020 & 2021 & 36,788 \\
\hline \multicolumn{2}{|c|}{ JUMLAH } & 156,649 \\
\hline
\end{tabular}

Sumber: data diolah dari data Seksi Pelayanan KPP Pratama Mataram Barat

Data yang digunakan dalam penelitian ini adalah data sekunder. Data tersebut meliputi WPOP yang menggunakan formulir 1770 S dan 1770SS yang terdata di KPP Pratama Mataram Barat. Dari data diatas dapat dilihat bahwa jumlah WPOP yang melakukan pelaporan SPT melalui e-filling tidak stabil atau menurun khususnya di tahun 2019-2020. Tahun pajak $2017 \mathrm{ke}$ tahun pajak 2018 penyampain SPT melalui Efilling mengalami peningkatan dari 40,125\% menjadi 41,740\%. Sedangkan dari Tahun 2018 ke Tahun 2019 mengalami penurunan dari 41,740 \% menjadi 37,996 \% dan dari Tahu 2019 ke tahun 2020 mengalami penurunan yakni dari 37,996 $\%$ menjadi $36,788 \%$.

Adapun data jumlah WPOP yang melakukan pelaporan SPT 1770 tahun 2017-2020 sebagai berikut: 
Tabel 2. Jumlah Penyampaian SPT Tahunan Menggunakan Formulir 1770 Melalui E-Filling

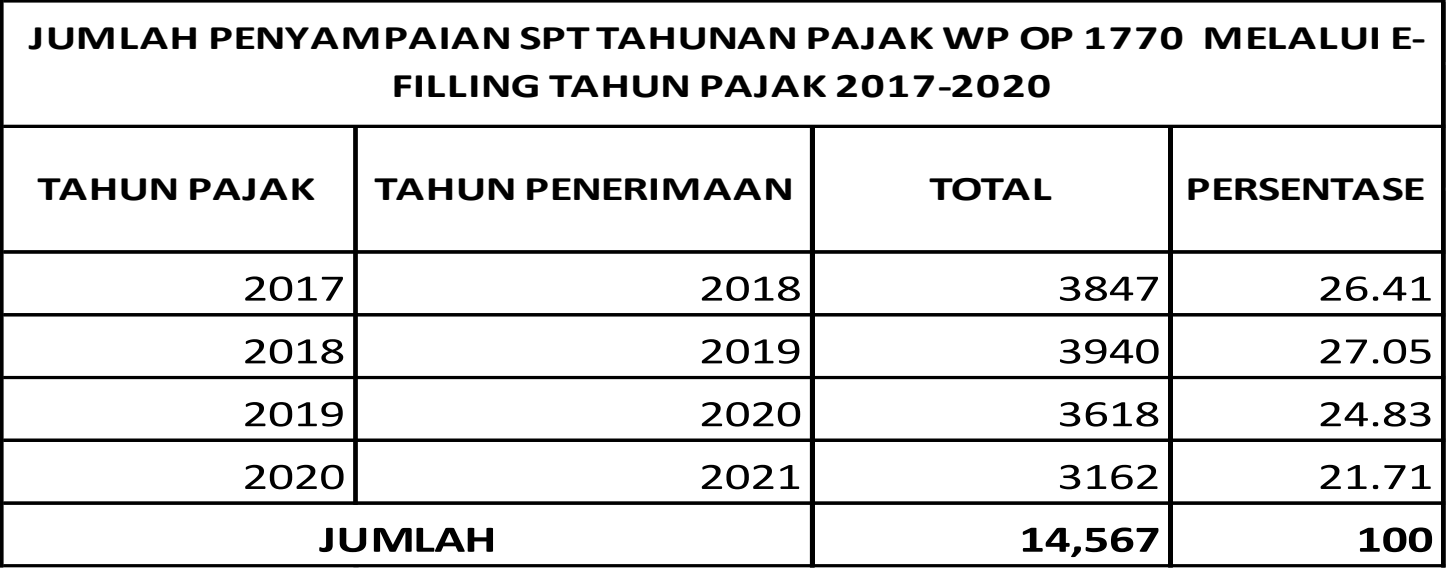

Sumber: data diolah dari data Seksi Pelayanan KPP Pratama Mataram Barat

Data yang digunakan dalam penelitian ini adalah data skunder. Data tersebut meliputi WPOP yang menggunakan formulir 1770 yang terdata di KPP Pratama Mataram Barat. Dari data diatas dapat dilihat bahwa jumlah WPOP yang melakukan pelaporan SPT melalui e-filling tidak stabil atau menurun khususnya di tahun 2019-2020. Tahun pajak 2017 ke tahun pajak 2018 pemyampai SPT melaui Efilling mengalami peningkatan dari 26,41 \% menjadi 27,05\%. Sedangkan dari Tahun 2018 ke Tahun 2019 mengalami penurunan dari 27,05\% menjadi 24,83\% dan dari Tahun 2019 ke tahun 2020 mengalami penurunan yakni dari 24,83\% menjadi 21,71\%.

Berdasarkan hasil penelitian diatas persentase jumlah wajib pajak orang pribadi yang melakukan pelaporan SPT Tahunan menggunakan formulir $1770 \mathrm{~S}$ dan formulir $1770 \mathrm{SS}$ melalui e-filling pada tahun pajak 2019 dengan tahun penerimaan 2020 mengalami penurunan sebesar $3,744 \%$, begitu juga dengan pajak tahun 2020 dengan tahun penerimaan 2021 mengalami penurunan sebesar $1,20 \%$. Begitu juga dengan persentase jumlah wajib pajak orang pribadi yang melakukan pelaporan SPT Tahunan menggunakan formulir 1770 melalui e-filling pada tahun pajak 2019 dengan tahun penerimaan 2020 mengalami penurunan sebesar 2,67\%, begitu juga dengan pajak tahun 2020 dengan tahun penerimaan 2021 mengalami penurunan sebesar 3,12\%.

Melihat persentase wajib pajak orang pribadi yang melaporkan SPT Tahunan melalui efilling dari tahun pelaporan 2020 dan Tahun 2021 yang masih cukup rendah, mengartikan bahwa masih banyak wajib pajak yang belum merasakan manfaat dari sistem pelayanan e-filling yang telah diberikan oleh KPP Pratama Mataram Barat, yang diharapkan dapat menjadi salah satu langkah dalam meningkatkan jumlah penyampaian SPT Tahunan khususnya di masa pandemi sehingga penerimaan Negara dapat terealisasi sesuai dengan rencana target yang ingin dicapai. Pada masa pandemic ini pemerintah melakukan kebijakan yang cukup ketat terkait penanggulangan pandemi, termasuk salah satunya penerapan social distancing atau pembatasan dalam bersosialisasi di masyarakat bahkan tidak boleh lebih dari 10 orang, dan ini berlaku bagi semua masyarakat Indonesia baik itu juga di lembaga pemerintah maupun lembaga swasta.

E-filling mulai diterapkan di KPP Pratama Mataram Barat pada tahun 2015, untuk pelaporan SPT Tahunan telah diatur dalam Peraturan Direktur Jendral Pajak Nomor PER-29/PJ/2014 tentang Tata Cara Penerimaan dan Pengelolaan Surat Pemberitahuan Tahunan. Penggunaan efilling di KPP Pratama Mataram Barat dibantu oleh semua Seksi yang ada disana karena KPP Pratama Mataram Barat menggunakan sistem piket disetiap harinya untuk mengkoordinasikan kegiatan salah satunya menerima SPT dan melakukan registrasi wajib pajak sesuai ketentuan yang berlaku. Dalam pelaksanaan penerapan e-filling sebagai sarana pelaporan SPT Tahunan Wajib Pajak Orang Pribadi, KPP Pratama Mataram Barat mempunyai Standart Operating Prosedur (SOP), Pelaporan e-filling bagi Wajib Pajak Orang Pribadi yang menjadi pedoman dan 
acuan bagi pegawai KPP Pratama Mataram Barat dengan melakukan tugas dan fungsinya. Adapun SOP tersebut dapat diuraikan melalui gambar berikut ini.

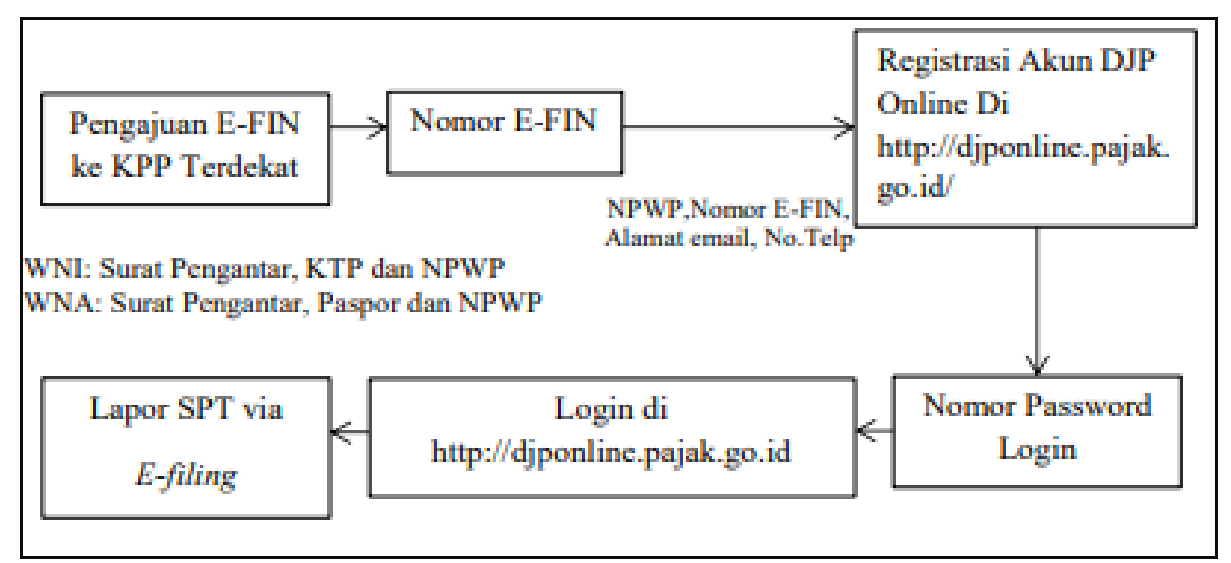

Gambar 1. Prosedur Pelaporan E-Filling

Pada gambar tersebut dapat diuraikan bahwa bagaimana alur pelaporan SPT Tahunan melalui efilling yang di terapkan di KPP Pratama Mataram Barat.

Berdasarkan wawancara yang telah dilakukan peneliti dengan salah satu pegawai KPP Pratama Barat Seksi Pelayanan mengungkapkan bahwa penerapan antara SOP dan praktik di lapangan secara garis besar telah berjalan sebagaimana mestinya. Pelaporan SPT tahunan bagi wajib pajak perorangan yang paling sering terjadi tiap tahun adalah pelaporan dilakukan pada saat akhir-akhir batas pelaporan SPT yang diberlakukan oleh KPP Mataram Barat. Hal ini sering menjadi masalah ditambah masih terdapat banyak kekurangan-kekurangan yang terjadi yang cukup mengganggu kenyamanan wajib pajak saat melaporkan SPT Tahunan secara elektronik melalui e-filling khususnya dia masa Pandemi ini. Dengan adanya penerapan e-filling di KPP Pratama Mataram Barat di masa pandemi, maka ada 4 konter untuk pelaporan SPT Tahunan. Yang mana konter 1 dan konter 2 merupakan tempat melakukan aktivasi E-FIN jika wajib pajak orang pribadi tidak memiliki nomor e-fin dan lupa nomor e-fin. Setelah mendapatkan nomor e-fin Wajib Pajak Orang Pribadi diarahkan ke konter 3 dan 4 untuk melakukan pelaporan SPT Tahunan melalui e-filling. Bagi Wajib Pajak Orang Pribadi yang berusia lanjut atau tidak memiliki email diberikan kemudahan oleh KPP untuk dilaporkan langsung. Ini disebabkan oleh kurangnya pengetahuan mereka tentang Informasi dan Teknologi. Sedangkan untuk melaporkan SPT Tahunan melalui e-filling membutuhkan kurang lebih 3 hari kerja untuk menerima bukti elektronik yang dikirimkan melalui email. Sistem ini diterapkan karena adanya wadah pandemic covid-19 untuk mengurangi kerumunan di KPP Pratama Mataram Barat.

Penerapan e-filling sebagai sarana penyampaian SPT Tahunan wajib pajak orang pribadi tentu akan memberikan dampak bagi wajib pajak orang pribadi dan pegawai pajak, baik dampak positif maupun dampak negatif. Dampak diterapkannya e-filling di KPP Pratama Mataram Barat bagi pegawai yaitu memudahkan pekerjaan dalam penerimaan SPT tahunan, mengurangi antrian di masa pandemic covid-19, memudahkan pengawasan, meningkatkan keefektifitasan dan keefisianan penggunaan anggaran. Sedangkan dampak bagi wajib pajak yaitu melaporkan SPT Tahunan melalui e-filling semua menjadi mudah, praktis, tidak membuang waktu, tidak perlu datang ke kantor pajak dan tidak perlu ongkos lebih jasa pengiriman, serta kerahasiaan data yang dikirim terjamin, serta memudahkan wajib pajak untuk melaporkan SPT Tahunannya dimana saja secara online tanpa perlu datang ke KPP wajib pajak terdaftar yang secara tidak langsung telah membantu pemerintah dalam mengurangi penyebaran virus corona atau covid-19. 
Secara umum e-filling memberikan kemudahan bagi wajib pajak orang pribadi karena wajib pajak dapat melaporkan SPT Tahunannya melalui online menggunakan e-filling yang dapat meminimalisir penyeberan virus covid-19 tanpa perlu datang ke kantor pajak. Sedangkan bagi pegawai pajak, e-filling tentu akan mengurangi beban kerja, memudahkan monitoring, perekaman data menjadi lebih cepat serta mengatasi masalah pada Seksi Pelayanan dan mengurangi tatap muka dengan wajib pajak di masa pandemic covid-19 ini. Sebaik-baiknya sistem yang diterapkan tentu akan menemui masalah, hal itu pula yang terjadi saat diberlakukannya sistem e-filling. Berbagai macam masalah yang dihadapi oleh wajib pajak orang pribadi dan pegawai pajak dalam penggunaan e-filling ini. Masalah yang dihadapi dalam penerapan e-filling di KPP Pratama Mataram Barat adalah banyaknya wajib pajak yang buta teknologi, tidak semua wajib pajak mempunyai email dan paham apa itu email. Masalah utama dan yang paling sering terjadi adalah adanya gangguan sistem. Selain wajib pajak yang kurng mengerti teknologi menjadi masalah tersendiri, ketidak pahaman wajib pajak dalam proses efilling menjadi lebih panjang dan lama karena wajib pajak yang tidak memiliki bahkan tidak tahu apa itu email. Selain itu, kebanyakan wajib pajak yang datang adalah wajib pajak yang baru pertama kali melaporkan sendiri SPT-nya sehingga dibutuhkan kesabaran ekstra untuk melayani dari proses aktivasi e-fin hingga proses pelaporan SPT Tahunan melalui e-filling. Serta dengan diterapkannya social distancing menyebabkan tidak optimalnya sosialisasi penerapan E-SPT ada masyarakat sehingga yang masih awam dengan penggunaan e-filing menjadi tidk dapat melaporkan SPT-nya tahun ini. Gangguan sistem akibat terlalu banyak yang mengakses website pajak yakni http://djponline.pajak.go.id sehingga menjadi masalah yang mengganggu kenyamanan wajib pajak dalam melaporkan SPT Tahunan, seringkali mengalami gangguan jaringan di waktu-waktu terakhir atau jatuh tempo khususnya pada saat bulan Maret 2021. Direktorat Jendral Pajak secara cepat merespon masalah yang terjadi dengan mengeluarkan Keputusan Direktorat Jendral Pajak Nomor KEP-49/PJ.2016 tentang Pengecualian Pengenaan Sanksi Administrasi Berupa Denda atas Keterlambatan Penyampaian Surat Pemberitahuan bagi wajib pajak orang pribadi yang menyampaikan SPT Tahuanan wajib pajak orang pribadi elektronik. Keputusan ini memutuskan bahwa wajib pajak orang pribadi yang menyampaikan SPT Tahunan dalam bentuk dokumen elektronik setelah batas waktu penyampaian SPT Tahunan pajak penghasilan wajib pajak orang pribadi akan dapat pengenaan sanksi administrasi berupa denda atas keterlmbatan.

\section{PENUTUP}

Berdasarkan hasil dan pembahasan penelitian kesimpulan yang dalam penelitian ini adalah Penerapan e-filling di KPP Pratama Mataram Barat pada masa pandemi telah sesuai dengan Tata Cara Pendaftaran berdasarkan peraturan perundang-undangan perpajakan dan ketentuan administrasi. Pemberlakuan social distancing pada masa pandemi covid 19 merupakan salah satu kendala dalam mensosialisasikan bentuk laporan SPT ke wajib pajak melalui e-filling. Kepatuhan wajib pajak orang pribadi dimasa pandemi covid 19 melaporkan SPT tahunan melalui E-filling lebih terkendala seperti wajib pajak orang pribadi kebanyakan melapor SPT tahunan pada akhir batas waktu laporan, tidak semua wajib pajak mengerti tentang teknologi seperti komputer, akses internet dan email, kemudian kurangnya pengetahuan wajib pajak orang pribadi dalam mengisi SPT Tahunan secara online sehingga banyak kesalahan dalam pengisian SPT serta sistem jaringan di website pajak on line yang sering mengalami gangguan akibat terlalu banyak wajib pajak orang pribadi yang mengakses website tersebut pada bulan laporan pajak tahunan. 


\section{DAFTAR PUSTAKA}

Direktorat Jendral Pajak.2004. Keputusan Direktorat Jendral Pajak Nomor KEP-88/PJ/2004 tentang Penyampaian Surat Pemberitahuan secara Elektronik. Jakarta.

http://djponline.pajak.go.id/ di Akses 1 Juli 2021

https://klikpajak.id/blog/perbedaan-formulir-1770-s-1770-ss-1770 di Akses 1 Juli 2021

https://bnpb.go.id/berita/presiden-tetapkan-covid19-sebagai-bencana-nasional

Liberti Pandinangan (2008). Modernisasi dan Reformasi Pelayanan Perpajakan. Jakarta: Elex Media Komputindo

Penyampaian Surat Pemberitahuan Online (e-filling). (Online) (http://www.kemenkeu.go.id/). di Akses 1 Juli 2021

Peraturan Direktorat Jendral Pajak Nomor Per-29/PJ/2014 tentang Tata Cara Penerimaan dan Pengolahan Surat Pemberitahuan Tahunan.

Peraturan Direktorat Jenderal Pajak Nomor: per- 39/PJ/2011. Tentang Tata Cara Penyampaian Surat Pemberitahuan Tahunan Bagi Wajib Pajak Orang Pribadi yang menggunakan Formulir 1770 S atau 1770 SS secara e-filing melalui website Direktorat Jenderal Pajak.

Peraturan Direktorat Jendral Pajak Nomor PER-03/PJ/2015 tentang Tata Cara Penyampaian Surat Pemberitahuan secara Elektronik.

Peraturan Menteri Keuangan Nomor 192/PMK.03/2007 Tentang Tata Cara Penetapan Wajib Pajak dengan Kriteria Tertentu dalam Rangka Pengembalian Pendahuluan Pembayaran Pajak.

Peraturan Direktur Jenderal Pajak nomor per 06/pj/2020 Tentang Tata cara penyampaian, penerimaan, dan pengolahan surat pemberitahuan pajak penghasilan tahun pajak 2019 sehubungan dengan pandemi coronavirus disease 2019

Supramono \& Damayanti (2005). Perpajakan Indonesia. Salatiga: Andi

Undang - undang Nomor 16 Tahun 2009 tentang perubahan atas Undang - undang Nomor 6 Tahun 1983 tentang Ketrntuan Umum dan Tata Cara Perpajakan 